\title{
Perspectives
}

\section{Thalassemia and Venous Thromboembolism}

\author{
Julien Succar, Khaled M. Musallam and Ali T. Taher
}

Department of Internal Medicine, Hematology-Oncology Division, American University of Beirut Medical Centre, Beirut, Lebanon

Correspondence to: Ali T. Taher, MD, FRCP, Professor of Medicine, Hematology-Oncology Division, Associate Chair, Research, Department of Internal Medicine, American University of Beirut Medical Center. P.O. Box: 11-0236, Riad El-Solh 1107 2020, Beirut, Lebanon. Phone: +961-1-350000; Fax:+961-1-370814; Email: ataher@aub.edu.1b

Competing interests: The authors have declared that no competing interests exist.

Published: May 25, 2011

Received: January 21, 2011

Accepted: May 24, 2011

Mediterr J Hematol Infect Dis 2011, 3: e2011025, DOI 10.4084/MJHID.2011.025

This article is available from: http://www.mjhid.org/article/view/7890

This is an Open Access article distributed under the terms of the Creative Commons Attribution License (http://creativecommons.org/licenses/by/2.0), which permits unrestricted use, distribution, and reproduction in any medium, provided the original work is properly cited.

Abstract: Although the life expectancy of thalassemia patients has markedly improved over the last few decades, patients still suffer from many complications of this congenital disease. The presence of a high incidence of thromboembolic events, mainly in thalassemia intermedia, has led to the identification of a hypercoagulable state in these patients. In this review, the molecular and cellular mechanisms leading to hypercoagulability in thalassemia are highlighted, with a special focus on thalassemia intermedia being the group with the highest incidence of thrombotic events as compared to other types of thalassemia. Clinical experience and available clues on optimal management are also discussed.

Introduction: The thalassemias, a group of inherited disorders of hemoglobin synthesis, are the most common monogenetic disease worldwide. ${ }^{1}$ Extremely diverse phenotypes exist within the thalassemia syndromes. At one end of the spectrum is thalassemia minor, a clinically silent, mildly hypochromic and microcytic anemia. At the other end is thalassemia major (TM) which refers to those patients whose clinical course is characterized by profound anemia, who are presented to medical attention in the first year of life, and who subsequently require regular blood transfusions for survival. ${ }^{2}$ The term thalassemia intermedia (TI) was first suggested to describe patients who had clinical manifestations that were too severe to be termed minor yet too mild to be termed major, although there remains substantial overlap between the three conditions. ${ }^{3}$ Our understanding of the molecular and pathophysiological mechanisms underlying the disease process in patients with TI has substantially increased over the past decade. ${ }^{4}$ Three main factors highlight the pathophysiology of TI, ineffective erythropoiesis, chronic anemia/hemolysis, and iron overload secondary to increased intestinal absorption. ${ }^{4}$ However, the extreme diversity in phenotypic expression in TI patients led to a wide variation in observed clinical complications. ${ }^{5}$ Among the clinical complications of TI that were found to occur at a higher rate than in patients with TM are thromboembolic events (TEE). ${ }^{6-7}$ We herein review hypercoagulability in patients with thalassemia and its translation into clinical TEE, with special emphasis on TI patients. 
Pathophysiology: Hypercoagulability in patients with thalassemia has been attributed to several risk factors. ${ }^{8}$ It is often a combination of these factors that leads to TEE.

It is widely accepted that patients with thalassemia have chronically activated platelets, and enhanced platelet aggregation, ${ }^{9}$ as confirmed by the increased expression of CD62P (P-selectin) and CD63, markers of in vivo platelet activation. ${ }^{10-11}$ Platelets in thalassemia have a shorter life span, particularly in splenectomized patients, due to enhanced consumption. $^{12}$ It has also been shown that splenectomized TM and non-splenectomized TI patients have 4 to 10 times more metabolites of prostacyclin (PGI2) and thromboxane A2 (TXA2), both markers of hemostatic activity, than controls. However, no significant difference was found between TM and TI patients. ${ }^{13}$ Thus, the higher rate of TEE in patients with TI compared to TM cannot be explained by abnormalities in platelet function, and shifts the attention to the pathogenic role of red blood cells (RBCs) described hereafter. Splenectomy also leads to higher platelet count. ${ }^{14-15}$

Furthermore, the oxidation of globin subunits in thalassemia erythroid cells leads to the formation of hemichromes, ${ }^{2}$ which precipitate, instigating heme disintegration and the eventual release of toxic nontransferrin-bound iron species. ${ }^{16}$ The free iron in turn catalyzes the formation of reactive oxygen species, leading to oxidation of membrane proteins and formation of red-cell "senescence" antigens like phosphatidylserine, ${ }^{17}$ which cause the thalassemic RBCs to become rigid, deformed, and to aggregate, resulting in premature cell removal. ${ }^{18}$ Thalassemic RBCs with negatively charged phospholipids have been shown to increase thrombin generation, ${ }^{19-20}$ as evidenced by studies using the protein annexin $\mathrm{V}$, a protein with high affinity and specificity for anionic phospholipids. $^{20}$ Studies have also shown that splenectomized patients have a higher number of negatively charged RBCs and increased thrombin generation. ${ }^{21-22}$ Thalassemic RBCs also have enhanced cohesiveness and aggregability. These abnormalities have been reduced to normal range after introducing a blood transfusion. ${ }^{23}$

TI patients were also found to have higher levels of procoagulant microparticles of RBC, leukocytic, and endothelial origins compared to controls. ${ }^{24}$

The presence of other peripheral blood elements in thalassemics such as E-selectin (ELAM-1), intercellular adhesion molecule-1 (ICAM-1), von Willebrand factor (VWF) and vascular cell adhesion molecule-1 (VCAM-1) indicates that endothelial injury or activation may be an aspect of the disease, aiding in the recruitment of white blood cells and RBCS, promoting thrombosis. ${ }^{25-26}$ Studies have demonstrated that RBCs from TM and TI patients show increased adhesion to cultured endothelial cells (EC). ${ }^{27}$ Butthep et al. showed that in addition to the presence of EC expressing adhesion molecules and tissue factor in the circulation, thalassemia patients also have decreased levels of Protein C and Protein S compared with normal. ${ }^{28}$ Prothrombin fragment 1.2 (F1.2), a marker of thrombin generation, is elevated in patients with TI. ${ }^{29}$

Prothrombotic mutations do not play a role in the hypercoagulability of thalassemia. Studies in Italy and Lebanon have revealed that the presence of factor $\mathrm{V}$ Leiden, prothrombin, and methylene tetrahydrofolate reductase mutations did not contribute to the risk of TEE in patients with thalassemia. ${ }^{30-31}$ The presence of cardiac, hepatic, or endocrine dysfunction may also contribute to the hypercoagulability in thalassemia. ${ }^{8}$

Clinical Experience: Epidemiological data on TEE in thalassemia are scarce. Borgna-Pignatti et al. surveyed nine Italian pediatric thalassemia centers, observing that $4 \%$ of the 683 patients with TM and $9.6 \%$ of the 52 patients with TI had experienced a TEE. ${ }^{6}$ The same group showed six years later that $1.1 \%$ of 720 patients with TM in seven Italian centers had thrombosis ${ }^{32}$. Cappellini et al. followed-up 83 patients with TI over 10 years, 82 of whom were splenectomized, and found that $29 \%(24 / 83)$ experienced a venous TEE. ${ }^{22}$ One study directly implicated TEE as the cause of death in $2.5 \%$ of transfusion-dependent thalassemia patients. ${ }^{33}$ After examining data from 8,860 patients in the Mediterranean area and Iran, Taher et al. observed that TEE occurred 4.38 times $(95 \% \mathrm{CI} 3.14-6.10, P<$ 0.001 ) more frequently in TI than TM, with more venous events occurring in TI and more arterial events occurring in TM (Figure 1). ${ }^{7}$ It was found that $14 \%$ of mortalities in the whole group were due to $\mathrm{TEE}^{7}$. Age above 20 years, splenectomy, family history of TEE, and previous TEE were identified as the main risk factors for thrombosis in TI. Furthermore, the study showed that $68 \%$ of TI patients that had a TEE had an average hemoglobin level of $<9 \mathrm{~g} / \mathrm{dl}$ and only 33\% were receiving regular blood transfusions, whereas 94\% were splenectomized. ${ }^{7}$ Moreover, patients receiving aspirin therapy had a significantly lower rate of recurrent TEE. ${ }^{7}$

The evidence for brain involvement in thalassemia dates back to 1972 where $20 \%$ of $138 \mathrm{TM}$ patients in Greece were found to have neurological deficits compatible with transient ischemic attacks (TIAs). ${ }^{34}$ Further evidence of TIAs causing neurological symptoms, such as headaches, hemiparesis, and seizures was shown in $2.2 \%$ of patients with $\mathrm{TM}$ in Italy. ${ }^{6}$ Although overt stroke occurs more frequently in 


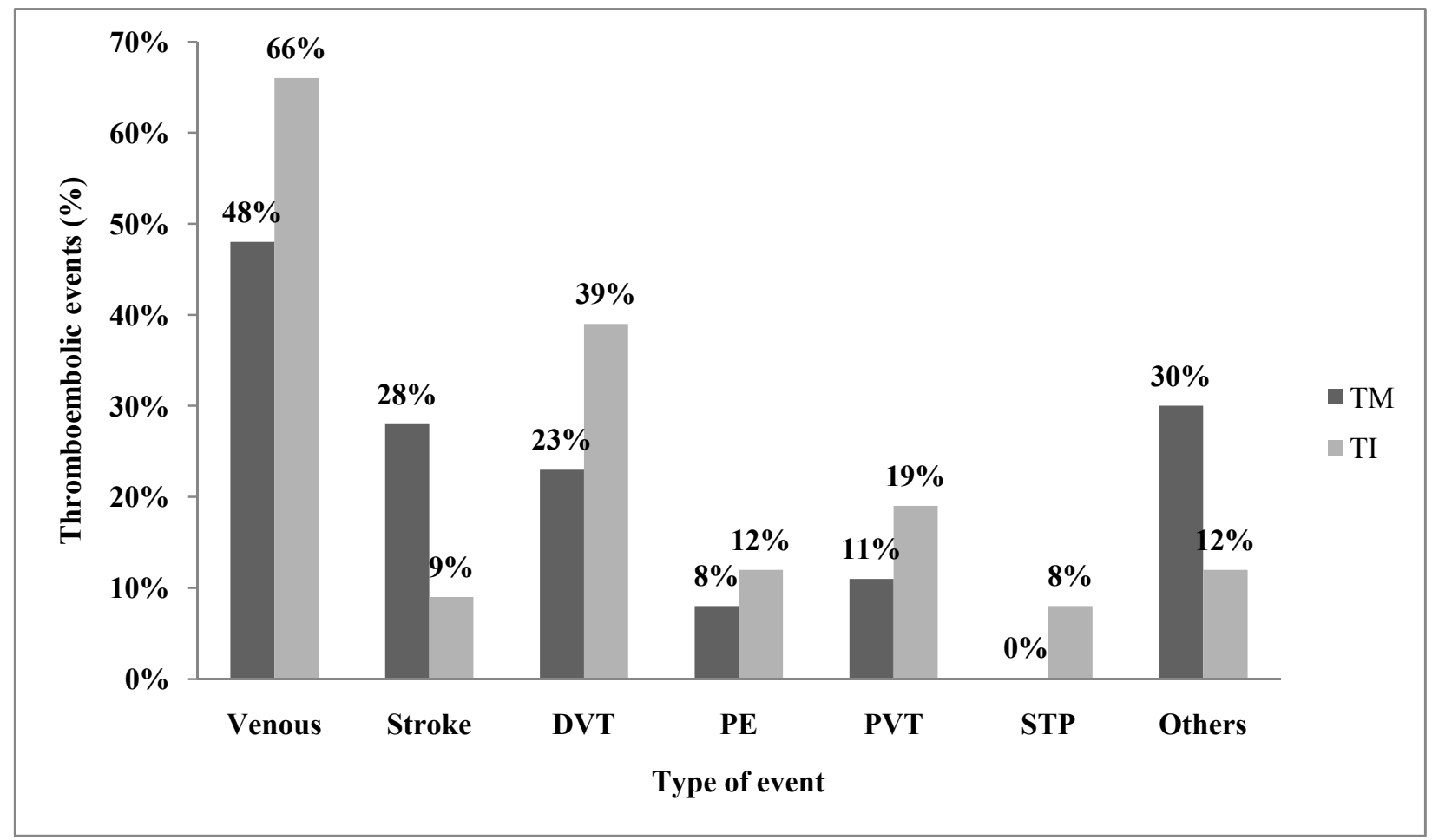

Figure 1. Type of thromboembolic events in thalassemia intermedia (TI) vs. thalassemia major $(\mathrm{TM}){ }^{7} \mathrm{DVT}=$ deep vein thrombosis, $\mathrm{PE}=$ pulmonary embolism, PVT = portal vein thrombosis, $\mathrm{STP}=$ superficial thrombophlebitis.

TM than TI $(28 \%$ vs. $9 \%$, respectively $){ }^{7}$ it has been shown that as many as $37.5 \%$ of patients with TI have asymptomatic brain damage on magnetic resonance imaging (MRI). ${ }^{34} \mathrm{~A}$ more recent study determined that splenectomized adults with TI show a rate of silent white matter lesions as high as $60 \%{ }^{35}$ The occurrence and multiplicity of the lesions were associated with older age (mean age of 36.1 years for lesion positivepatients vs. 26.1 years for lesion-negative patients) and transfusion naivety $(83.3 \%$ of lesion-positive patients have never had a transfusion vs. $25 \%$ of lesionnegative patients). ${ }^{35}$

In order to obtain much needed clinical data on the optimal management of patients with TI, the Overview on Practices in Thalassemia Intermedia Management Aiming for Lowering Complication rates Across a Region of Endemicity (OPTIMAL CARE) study evaluated 584 patients with TI at six comprehensive care centers (Lebanon, Italy, Iran, Egypt, United Arab Emirates, and Oman) for the associations between patient and disease characteristics, treatment received, and the rate of complications. ${ }^{5}$ The study analyzed complications against the parameters of age, gender, serum ferritin level, hemoglobin level, splenectomy, transfusion, hydroxyurea, and iron chelation therapy. Thrombosis was the $5^{\text {th }}$ most common complication, affecting $14 \%$ of the patient population. On multivariate analysis, splenectomy, age above 35 years, and a serum ferritin level $\geq 1000 \mu \mathrm{g} / \mathrm{l}$ were associated with a higher risk for thrombosis. ${ }^{5}$ Conversely, a positive history of transfusion and a hemoglobin level $\geq 9 \mathrm{~g} / \mathrm{dl}$ were found to be protective against thrombosis (Table 1). ${ }^{5}$ Another study further confirmed the higher occurrence of thrombosis with advancing age. ${ }^{36}$

In an effort to further understand the effect of splenectomy on TEE, a sub-study of the OPTIMAL CARE examined the characteristics of splenectomized patients with TI who develop TEE aiming to identify high-risk patients who deserve further consideration for preventive strategies. ${ }^{37}$ Splenectomized patients with documented TEE (Group I, $\mathrm{n}=73$ ) were age- and sexmatched with splenectomized patients without TEE (Group II) and non-splenectomized patients without TEE (Group III). The study determined that splenectomized TI patients who experience TEE are characterized by high nucleated RBC $\left(\geq 300 \times 10^{6} / 1\right)$ and platelet counts $\left(\geq 500 \times 10^{9} / 1\right)$, are more likely to have evidence of pulmonary hypertension (PHT) and be transfusion naïve. As such, the authors suggest that splenectomized TI patients at risk of developing TEE may be identified early on by these laboratory markers, presence of PHT, and transfusion status. ${ }^{37}$ The study further examined how long it took for a TEE to develop following splenectomy and found the median time to thrombosis to be 8 years. ${ }^{37}$ The delay indicates that the etiology behind TEE in splenectomized patients with TI is not an acute complication, but a manifestation of a chronic underlying process, further emphasizing the need for a long-term treatment modality for prevention. ${ }^{37}$ 
Table 1. Predictors of thrombosis in the OPTIMAL CARE study. ${ }^{5}$

\begin{tabular}{llll}
\hline Parameter & Adjusted OR & $\mathbf{9 5 \%}$ CI & P-value \\
\hline Age $>35$ & 2.59 & $1.39-4.87$ & 0.003 \\
\hline Female & 1.27 & $0.74-2.19$ & 0.387 \\
\hline Hemoglobin $\geq 9 \mathrm{~g} / \mathrm{dl}$ & 0.41 & $0.23-0.71$ & 0.001 \\
\hline Ferritin $\geq 1000 \mu \mathrm{g} / \mathrm{L}$ & 1.86 & $1.09-3.16$ & 0.023 \\
\hline Splenectomy & 6.59 & $3.09-14.05$ & $<0.001$ \\
\hline Transfusion & 0.28 & $0.16-0.48$ & $<0.001$ \\
\hline Hydroxyurea & 0.56 & $0.28-1.10$ & 0.090 \\
\hline Iron chelation & 0.97 & $0.56-1.68$ & 0.912 \\
\hline
\end{tabular}

Management: The reduction of procoagulant RBCs by transfusion has been suggested as a reason behind the lower rate of TEE in transfused vs. non-transfused patients. ${ }^{5,735,37}$ As such, transfusion therapy may be worthwhile to prevent the occurrence of TEE, especially in TI patients in whom current practice does not necessarily recommend transfusions. However, this needs to be prospectively evaluated.

Since splenectomy is a major contributor to TEE in patients with thalassemia, reassessment of the procedure and appropriate risk benefit-evaluation is called for. This is also important because of its correlation with other complications such as osteoporosis, PHT, cholelithiasis, hypothyroidism, diabetes mellitus, heart failure, increased susceptibility to infection, and leg ulcers in TI. ${ }^{5}$

The literature lacks proper evidence on the role of antiplatelet or anticoagulant agents in the management of thalassemia. ${ }^{8}$ The lower recurrence of TEE in TI patients who took aspirin after their first TEE, when compared to those who did not, suggests a potential role for aspirin. ${ }^{7}$ Moreover, the association of higher platelet counts with TEE in patients with TI further suggests a role for aspirin in this patient population. ${ }^{37}$

Fetal hemoglobin inducing agents like decitabine and hydroxycarbamide were also shown to lower plasma markers of thrombin generation. ${ }^{29}$ Hydroxycarbamide may modulate hypercoagulability in several ways, it may reduce phospholipid expression on the surface of RBCs and platelets, and decrease
$\mathrm{RBC}$ adhesion to thrombospondin, a thrombin sensitive protein. ${ }^{29}$ It may also decrease leukocyte count, particularly monocytes expressing transcription factor, in addition to being a nitric oxide donor. ${ }^{38}$

It is recommended that each patient be assessed individually and assigned a personalized thrombotic risk based on intrinsic (thalassemia type, number of circulating RBCs, etc) and extrinsic factors (splenectomy, transfusion status, etc).$^{29}$ High nucleated RBC and platelet counts, evidence of PHT, and transfusion naivety can be used as indicators of TEE for splenectomized patients with TI and could be practical in the clinical setting. ${ }^{37}$ Such a riskassessment model (RAM) would be valuable in identifying high-risk patients and targeting them for further testing. The RAM could serve as a guideline for preventative treatment and significantly decrease morbidity and mortality. ${ }^{29}$ Other diagnostic tests are being explored to help identify patients at risk, with promising preliminary results. ${ }^{39}$

Conclusions: The hypercoagulable state in thalassemia is due to multiple elements, a combination of which is often the drive behind a clinical TEE. Splenectomy and transfusion naivety are increasingly highlighted as important risk factors for TEE, especially in patients with TI. An individualized approach is recommended to establish an optimal strategy for preventing the occurrence of this complication if thalassemia.

\section{References:}

1. Weatherall DJ, Clegg JB. The thalassaemia syndromes. 4th ed. Oxford; Malden, MA: Blackwell Science; 2001. doi:10.1002/9780470696705

2. Rund D, Rachmilewitz E. Beta-thalassemia. N Engl J Med 2005; 353:1135-1146. doi:10.1056/NEJMra050436 PMid:16162884

3. Sturgeon P, Itano HA, Bergren WR. Genetic and biochemical studies of intermediate types of Cooley's anaemia. Br J Haematol 1955; 1:264-277. doi:10.1111/j.1365-2141.1955.tb05509.x PMid:13240015 
4. Taher A, Isma'eel H, Cappellini MD. Thalassemia intermedia: revisited. Blood Cells Mol Dis 2006; 37:12-20. doi:10.1016/j.bcmd.2006.04.005 PMid:16737833

5. Taher AT, Musallam KM, Karimi M, El-Beshlawy A, Belhoul $\mathrm{K}$, Daar S, et al. Overview on practices in thalassemia intermedia management aiming for lowering complication rates across a region of endemicity: the OPTIMAL CARE study. Blood 2010; 115:1886-1892. PMid:20032507

6. Borgna Pignatti C, Carnelli V, Caruso V, Dore F, De Mattia D, Di Palma A, et al. Thromboembolic events in beta thalassemia major: an Italian multicenter study. Acta Haematol 1998; 99:7679. doi:10.1159/000040814 PMid:9554453

7. Taher A, Isma'eel H, Mehio G, Bignamini D, Kattamis A, Rachmilewitz EA, et al. Prevalence of thromboembolic events among 8,860 patients with thalassaemia major and intermedia in the Mediterranean area and Iran. Thromb Haemost 2006; 96:488491. PMid:17003927

8. Taher AT, Otrock ZK, Uthman I, Cappellini MD. Thalassemia and hypercoagulability. Blood Rev 2008; 22:283-292. doi:10.1016/j.blre.2008.04.001 PMid:18511163

9. Winichagoon P, Fucharoen S, Wasi P. Increased circulating platelet aggregates in thalassaemia. Southeast Asian J Trop Med Public Health 1981; 12:556-560. PMid:7344105

10. Del Principe D, Menichelli A, Di Giulio S, De Matteis W, Cianciulli P, Papa G. PADGEM/GMP-140 expression on platelet membranes from homozygous beta thalassaemic patients. Br J Haematol 1993; 84:111-117. doi:10.1111/j.13652141.1993.tb03033.x PMid:7687856

11. Ruf A, Pick M, Deutsch V, Patscheke H, Goldfarb A, Rachmilewitz EA, et al. In-vivo platelet activation correlates with red cell anionic phospholipid exposure in patients with betathalassaemia major. $\mathrm{Br} \mathrm{J}$ Haematol 1997; 98:51-56. doi:10.1046/j.1365-2141.1997.1502965.x PMid:9233563

12. Eldor A, Krausz Y, Atlan H, Snyder D, Goldfarb A, Hy-Am E, et al. Platelet survival in patients with beta-thalassemia. Am J Hematol 1989; 32:94-99. doi:10.1002/ajh.2830320204 PMid:2757016

13. Eldor A, Lellouche F, Goldfarb A, Rachmilewitz EA, Maclouf J. In vivo platelet activation in beta-thalassemia major reflected by increased platelet-thromboxane urinary metabolites. Blood 1991; 77:1749-1753. PMid:2015401

14. Cappellini MD, Grespi E, Cassinerio E, Bignamini D, Fiorelli G. Coagulation and splenectomy: an overview. Ann N Y Acad Sci $2005 ; \quad 1054: 317-324 . \quad$ doi:10.1196/annals.1345.039 PMid: 16339680

15. Atichartakarn V, Angchaisuksiri P, Aryurachai K, Chuncharunee $\mathrm{S}$, Thakkinstian A. In vivo platelet activation and hyperaggregation in hemoglobin E/beta-thalassemia: a consequence of splenectomy. Int J Hematol 2003; 77:299-303. doi:10.1007/BF02983790 PMid:12731676

16. Hershko C, Graham G, Bates GW, Rachmilewitz EA. Nonspecific serum iron in thalassaemia: an abnormal serum iron fraction of potential toxicity. Br J Haematol 1978; 40:255-263. doi:10.1111/j.1365-2141.1978.tb03662.x PMid:708645

17. Kuypers FA, de Jong K. The role of phosphatidylserine in recognition and removal of erythrocytes. Cell Mol Biol (Noisyle-grand) 2004; 50:147-158.

18. Tavazzi D, Duca L, Graziadei G, Comino A, Fiorelli G, Cappellini MD. Membrane-bound iron contributes to oxidative damage of beta-thalassaemia intermedia erythrocytes. $\mathrm{Br} \mathrm{J}$ Haematol 2001; 112:48-50. doi:10.1046/j.13652141.2001.02482.x PMid:11167782

19. Borenstain-Ben Yashar V, Barenholz Y, Hy-Am E, Rachmilewitz EA, Eldor A. Phosphatidylserine in the outer leaflet of red blood cells from beta-thalassemia patients may explain the chronic hypercoagulable state and thrombotic episodes. Am J Hematol 1993; 44:63-65. doi:10.1002/ajh.2830440114

20. Helley D, Eldor A, Girot R, Ducrocq R, Guillin MC, Bezeaud A. Increased procoagulant activity of red blood cells from patients with homozygous sickle cell disease and beta-thalassemia. Thromb Haemost 1996; 76:322-327. PMid:8883264

21. Atichartakarn V, Angchaisuksiri P, Aryurachai K, Onpun S, Chuncharunee S, Thakkinstian A, et al. Relationship between hypercoagulable state and erythrocyte phosphatidylserine exposure in splenectomized haemoglobin E/beta-thalassaemic $\begin{array}{lllll}\text { patients. } & \mathrm{Br} & \mathrm{J} & \text { Haematol 2002; } & 118: 893-898\end{array}$ doi:10.1046/j.1365-2141.2002.03711.x PMid:12181063

22. Cappellini MD, Robbiolo L, Bottasso BM, Coppola R, Fiorelli G, Mannucci AP. Venous thromboembolism and hypercoagulability in splenectomized patients with thalassaemia intermedia. $\mathrm{Br} \quad \mathrm{J}$ Haematol 2000; 111:467-473. doi:10.1046/j.1365-2141.2000.02376.x PMid:11122086

23. Chen S, Eldor A, Barshtein G, Zhang S, Goldfarb A, Rachmilewitz E, et al. Enhanced aggregability of red blood cells of beta-thalassemia major patients. Am J Physiol 1996; 270:H1951-1956. PMid:8764243

24. Habib A, Kunzelmann C, Shamseddeen W, Zobairi F, Freyssinet JM, Taher A. Elevated levels of circulating procoagulant microparticles in patients with beta-thalassemia intermedia. Haematologica 2008; 93:941-942. doi:10.3324/haematol.12460 PMid:18460647

25. Butthep P, Bunyaratvej A, Funahara Y, Kitaguchi H, Fucharoen $\mathrm{S}$, Sato $\mathrm{S}$, et al. Alterations in vascular endothelial cell-related plasma proteins in thalassaemic patients and their correlation with clinical symptoms. Thromb Haemost 1995; 74:1045-1049. PMid:8560411

26. Butthep P, Bunyaratvej A, Funahara Y, Kitaguchi H, Fucharoen $\mathrm{S}$, Sato S, et al. Possible evidence of endothelial cell activation and disturbance in thalassemia: an in vitro study. Southeast Asian J Trop Med Public Health 1997; 28 Suppl 3:141-148A. PMid:9640617

27. Hovav T, Goldfarb A, Artmann G, Yedgar S, Barshtein G. Enhanced adherence of beta-thalassaemic erythrocytes to endothelial cells. $\mathrm{Br} \mathrm{J}$ Haematol 1999; 106:178-181. doi:10.1046/j.1365-2141.1999.01489.x PMid:10444184

28. Butthep P, Rummavas S, Wisedpanichkij R, Jindadamrongwech S, Fucharoen S, Bunyaratvej A. Increased circulating activated endothelial cells, vascular endothelial growth factor, and tumor necrosis factor in thalassemia. Am J Hematol 2002; 70:100-106. doi:10.1002/ajh.10101 PMid:12111782

29. Cappellini MD, Motta I, Musallam KM, Taher AT. Redefining thalassemia as a hypercoagulable state. Ann N Y Acad Sci 2010; 1202:231-236. doi:10.1111/j.1749-6632.2010.05548.x PMid:20712798

30. Zalloua PA, Shbaklo H, Mourad YA, Koussa S, Taher A. Incidence of thromboembolic events in Lebanese thalassemia intermedia patients. Thromb Haemost 2003; 89:767-768. PMid:12669135

31. Iolascon A, Giordano P, Storelli S, Li HH, Coppola B, Piga A, et al. Thrombophilia in thalassemia major patients: analysis of genetic predisposing factors. Haematologica 2001; 86:11121113. PMid: 11602424

32. Borgna-Pignatti $\mathrm{C}$, Rugolotto $\mathrm{S}$, De Stefano $\mathrm{P}$, Zhao $\mathrm{H}$, Cappellini MD, Del Vecchio GC, et al. Survival and complications in patients with thalassemia major treated with transfusion and deferoxamine. Haematologica 2004; 89:11871193. PMid: 15477202

33. Zurlo MG, De Stefano P, Borgna-Pignatti C, Di Palma A, Piga $A$, Melevendi C, et al. Survival and causes of death in thalassaemia major. Lancet 1989; 2:27-30. doi:10.1016/S0140-6736(89)90264-X

34. Manfre L, Giarratano E, Maggio A, Banco A, Vaccaro G, Lagalla R. MR imaging of the brain: findings in asymptomatic patients with thalassemia intermedia and sickle cell-thalassemia disease. AJR Am J Roentgenol 1999; 173:1477-1480. PMid: 10584785

35. Taher AT, Musallam KM, Nasreddine W, Hourani R, Inati A, Beydoun A. Asymptomatic brain magnetic resonance imaging abnormalities in splenectomized adults with thalassemia intermedia. J Thromb Haemost 2010; 8:54-59. doi:10.1111/j.1538-7836.2009.03651.x PMid:19817994

36. Taher AT, Musallam KM, El-Beshlawy A, Karimi M, Daar S, Belhoul K, et al. Age-related complications in treatment-naive patients with thalassaemia intermedia. Br J Haematol 2010; 150:486-489. PMid:20456362

37. Taher AT, Musallam KM, Karimi M, El-Beshlawy A, Belhoul K, Daar S, et al. Splenectomy and thrombosis: the case of 
thalassemia intermedia. J Thromb Haemost 2010; 8:2152-2158. doi:10.1111/j.1538-7836.2010.03940.x PMid:20546125

38. Sumiyoshi A, Thakerngpol K, Sonakul D. Pulmonary microthromboemboli in thalassemic cases. Southeast Asian J Trop Med Public Health 1992; 23 Suppl 2:29-31.
39. Tripodi A, Cappellini MD, Chantarangkul V, Padovan L, Fasulo MR, Marcon A, et al. Hypercoagulability in splenectomized thalassemic patients detected by whole-blood thromboelastometry, but not by thrombin generation in plateletpoor plasma. Haematologica 2009; 94:1520-1527. doi:10.3324/haematol.2009.010546 PMid:19648162 PMCid:2770962 